\title{
A New Guaiane Mannoside from a Eutypa-like Fungus Isolated from Murraya paniculata in Brazil
}

\author{
Afonso D. L. Souza, ${ }^{* \#, a}$ Edson Rodrigues-Filho, ${ }^{a}$ Antonia Q. L. Souza, ${ }^{b}$ \\ Flavio Henrique-Silva ${ }^{b}$ and José O. Pereira ${ }^{c}$
}

${ }^{a}$ Departamento de Química, Universidade Federal de São Carlos, CP 676, 13565-905 São Carlos-SP, Brazil

${ }^{b}$ Departamento de Genética e Evolução, Universidade Federal de São Carlos, CP 676, 13565-905 São Carlos-SP, Brazil

${ }^{c}$ Faculdade de Ciências Agrárias, Universidade Federal do Amazonas, 69077-000 Manaus-AM, Brazil

\begin{abstract}
Um fungo semelhante aos do gênero Eutypa foi isolado da madeira do caule de Murraya paniculata. Cultivado em meio líquido, o fungo produziu o novo sesquiterpeno do tipo guaiano $(1 R, 4 S, 5 S, 7 R, 10 R)$-10-hidroxiguaianol-10- $O$ - $\beta$-manopiranosídeo e um diastereômero da harzialactona A, a 3-hidróxi-5-fenilmetil-(3S,5R)-tetraidrofuran-2-ona, obtida pela primeira vez como produto natural. As estruturas desses metabólitos foram elucidadas com base na análise dos seus respectivos dados espectroscópicos.
\end{abstract}

A Eutypa-like fungus was isolated from the stems of Murraya paniculata. The fungus was cultivated in liquid medium and produced the new guaiane-type sesquiterpenoid $(1 R, 4 S, 5 S, 7 R, 10 R)$ 10-hydroxyguaianol 10-O- $\beta$-mannopyranoside and the 3-hydroxy-5-phenylmethyl-(3S,5R)tetrahydrofuran-2-one, a diastereomer of harzialactone A, obtained for the first time from a natural source. The structures of these metabolites were elucidated based on analysis of their spectroscopic data.

Keywords: Eutypa-like fungus, endophytic fungus, Murraya paniculata, guaiane mannoside, harzialactone A diastereomer

\section{Introduction}

Murraya paniculata (L.) Jack is a small Rutaceae tree native from Asia and introduced in Brazil for ornamental purposes many years ago. A chemical study of these plant collected in São Paulo State, Brazil, showed a different chemical profile when compared with those studies using plant material collected in Asian countries. ${ }^{1}$ As part of a program to investigate this apparent deviation of the plant secondary metabolism, endophytic microorganisms were seasonally gathered from all tissues of four specimens of M. paniculata plants. $^{2}$ One of these microorganisms, Eupenicillium sp., produces a series of spiroquinazoline alkaloids containing anthranilic acid residue in their structure. The influence of the presence of that and other fungi on the mentioned deviation has been discussed. ${ }^{3}$ Several strains of

*e-mail: souzadq@ufam.edu.br

"Present address: Departamento de Química, Mini-Campus, Bloco B, Sala B-13, Universidade Federal do Amazonas, 69077-000 ManausAM, Brazil a Eutypa-like fungus were also isolated from M. paniculata woods. ${ }^{2}$ Species of Eutypa are pathogenic to many plants. For example, Eutypa lata is a grapevine fungal pathogen that causes the "Eutyposis" or "dying-arm disease", a perennial canker disease that is progressive over several years, and affects vineyards worldwide resulting in a serious economic problem in major wine grape producing areas. Several acetylenic phenols and chromene metabolites were isolated from this fungus and some of them have proved to be toxic. ${ }^{4-6}$ One of the Eutypa-like isolates, named as FED-3, has been studied to characterize its metabolites. This paper report the identification of the new sesquiterpene $(1 R, 4 S, 5 S, 7 R, 10 R)$ 10-hydroxyguaianol 10-O- $\beta$-mannopyranoside (1), and 3-hydroxy-5-phenylmethyl-(3S,5R)-tetrahydrofuran-2-one (2), isolated from the Eutypa-like strain FED-3.

\section{Results and Discussion}

Compound 1 was isolated as viscid oil. Its IR spectrum displayed typical absorption bands for hydroxyl groups at 
$3400 \mathrm{~cm}^{-1}, \mathrm{C}-\mathrm{O}$ at 1065 and $1019 \mathrm{~cm}^{-1}$, and $\mathrm{C}=\mathrm{C}$ at 1643 $\mathrm{cm}^{-1}$. ESI mass spectrum in positive ion mode revealed a low intensity ion at $m / z 385\left([\mathrm{M}+\mathrm{H}]^{+}\right)$, and intense ion peaks at $m / z, 407\left([\mathrm{M}+\mathrm{Na}]^{+}\right), 423\left([\mathrm{M}+\mathrm{K}]^{+}\right)$and 181 $\left([\text { hexose }+\mathrm{H}]^{+}\right)$. In negative ion mode, ion peaks at $\mathrm{m} / \mathrm{z}, 383$ $\left([\mathrm{M}-\mathrm{H}]^{-}\right), 419\left([\mathrm{M}+\mathrm{Cl}]^{-}\right)$and $179\left([\text { hexose }-\mathrm{H}]^{-}\right)$were recorded. The ${ }^{1} \mathrm{H}$ NMR spectrum of $\mathbf{1}$ displayed signals for a methyl doublet at $\delta 0.91(J=6.9 \mathrm{~Hz})$, a methyl singlet at $\delta 1.21$, a broad olefinic methyl singlet at $\delta 1.68$, two vinylic hydrogen multiplets at $\delta 4.55$ and 4.67 , several low-resolution multiplets at $\delta$ 1.2-2.6 accounting for 14 protons, and characteristic sugar resonances at $\delta 4.74(1 \mathrm{H}$, $J=0.7 \mathrm{~Hz}$ ) and 3.2-3.9. A total of 21 carbon signals were detected in the ${ }^{13} \mathrm{C}$ NMR spectrum, including those for a hexose moiety and an isopropenyl double bond $(\delta 108.5$ and 153.7). Combined analysis of these and other NMR, IR and ESI mass spectral data are in agreement with the molecular formula $\mathrm{C}_{21} \mathrm{H}_{36} \mathrm{O}_{6}$. Furthermore, the tracking of correlations in the ${ }^{1} \mathrm{H}^{-1} \mathrm{H}$ COSY, HSQC and HMBC revealed $\mathbf{1}$ as a guaiane-type sesquiterpenoid with a hexose moiety at $\mathrm{C}-10$ (Table 1). This hexose was determined as mannose by the coupling constants of $0.7 \mathrm{~Hz}$ between $\mathrm{H}-1^{\prime}$ at $\delta 4.74(d)$ and $\mathrm{H}-2^{\prime}$ at $\delta 3.84(d d)$ and of $3.2 \mathrm{~Hz}$ between $\mathrm{H}-2^{\prime}$ and $\mathrm{H}-3^{\prime}$ at $\delta 3.46(d d)$, while $\mathrm{H}-4^{\prime}$ at $\delta 3.57(t)$ is coupled with $\mathrm{H}-3^{\prime}$ and $\mathrm{H}-5^{\prime}$ at $\delta 3.19(d d d)$ by the same coupling constant of 9.5 Hz. Further, it was noted the H-1', H-3' and H-5' atoms with NOESY correlations one each other and the absence of such correlation type between the H-2 ${ }^{\prime}$ and H-4' atoms, ratifying the axial orientation for all hydrogen atoms at the hexose group, except for H-2' (Figure 1). The linkage of the mannose with the aglycone moiety was determined by the anomeric H-1' HMBC correlation with a tertiary carbinolic carbon at $\delta 83.3$. Hydrogens of the methyl group at $\delta 1.21(s)$ are also in HMBC correlation with this carbon and with a methylene and a methine ones, at $\delta 31.4$ and 55.5, respectively. According to the COSY, the hydrogens connected to these carbons do not couple to each other, shown that the mannose is linked to a carbon of the aglycone of $\mathbf{1}$ that is connected to a methyl, a methylene and methine carbons. For characterize this aglycone as a guaiane-type structure it was fundamental the ${ }^{1} \mathrm{H}^{-1} \mathrm{H}$ COSY correlation. First of all, it was noted that the hydrogen at $\delta 2.30$, with HSQC correlation to the methine carbon at $\delta 55.5$, couples with other methine hydrogen at $\delta 2.12$ and two other hydrogens at $\delta 1.54$ and 1.72 , linked to a methylene carbon at $\delta 26.9$. The hydrogen at $\delta 1.54$ couples also with other methylene one at $\delta 1.29$, which is geminal with another superposed with that at $\delta 1.72$ and linked to a carbon at $\delta 31.5$. A methine hydrogen at $\delta 2.03$, connected to a carbon at $\delta 40.0$ (HSQC), couples with these later methylene hydrogens as well with hydrogens of a methyl group at $\delta 0.91$, which are linked to a carbon at $\delta 16.7$ (HSQC) and have HMBC correlations with the carbon atoms at $\delta 31.5$ and 40.0, as also with a carbon atom at $\delta 47.2$. This later is connected to the mentioned methine hydrogen at $\delta 2.12$ coupled to that other at $\delta 2.30$, as established above. In this way the $\mathrm{C}-1$ to $\mathrm{C}-5$ pentacyclic ring system of $\mathbf{1}$ was completely characterized, having a methyl group (C-15) linked to the $\mathrm{C}-4$. The heptacyclic ring system of $\mathbf{1}$ was typified by similar way, as one can deduce through correlation data in Table 1.

The relative stereochemistry of the guaiane moiety of $\mathbf{1}$ was attributed by the NOESY and nOe space interactions (Figure 1). The most important ones are that among H-1, H-4 and $\mathrm{H}-5$, that become apparent the $c i s$-fusion of the guaiane rings as well as the $\beta$-orientation of the $\mathrm{C}-15$ methyl group at C-4; between $\mathrm{H}-5$ and $\mathrm{H}-7$, by what the $\mathrm{C}-11$ to $\mathrm{C}-13$ propenyl group at $\mathrm{C}-7$ has $\beta$-orientation; as well between H-7 and H-2', more compatible with the mannose linked in $\alpha$-orientation to $\mathrm{C}-10$. Therefore, the assignment of all the hydrogen and carbon signals as well as their respective
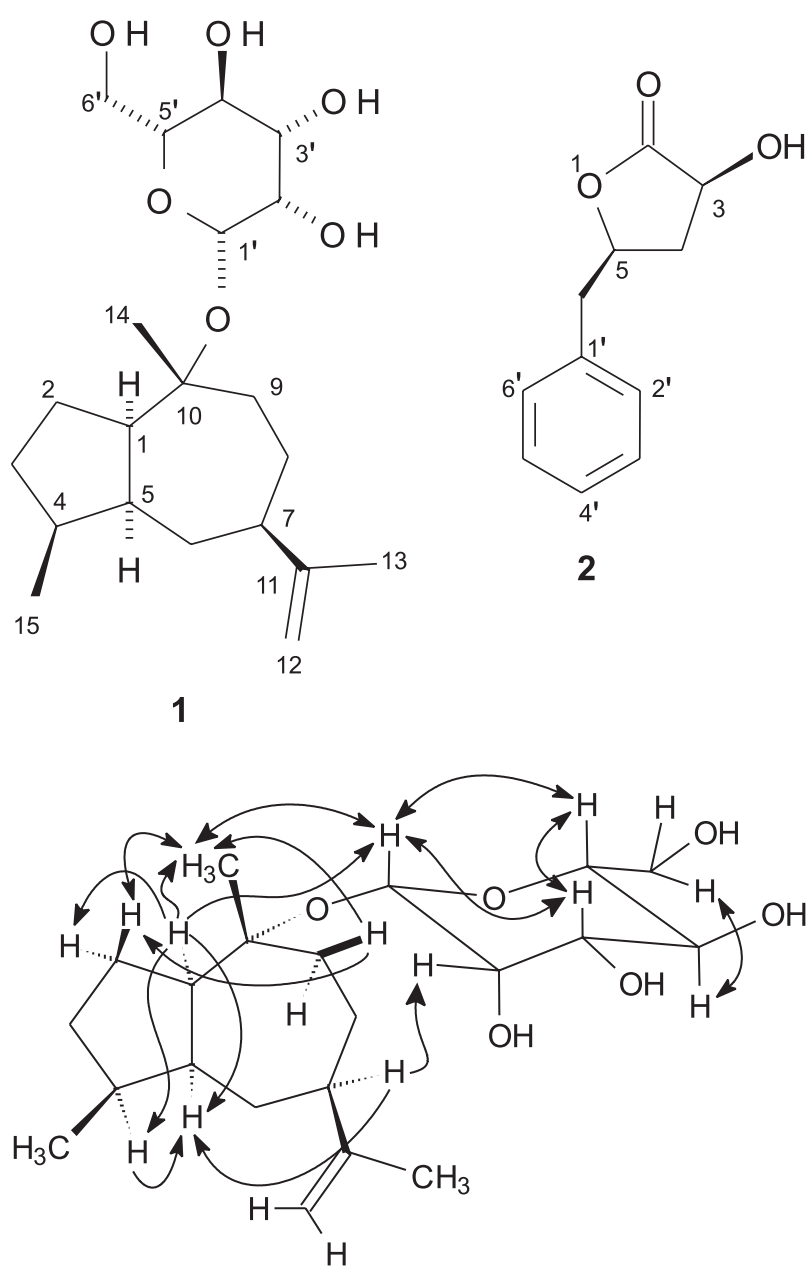

Figure 1. NOESY and nOe correlations for compound 1. Arrows with only one head represent correlations confirmed by nOe experiments. 
Table 1. NMR data for compound $1(1 R, 4 S, 5 S, 7 R, 10 R)$-10-hydroxyguaianol 10-O- $\beta$-mannopyranoside (methanol-d4)

\begin{tabular}{|c|c|c|c|c|c|}
\hline \multirow[t]{2}{*}{$\mathrm{C}$} & \multicolumn{2}{|r|}{ Chemical shifts $-\delta$} & \multicolumn{3}{|c|}{ Observed correlations } \\
\hline & ${ }^{13} \mathrm{C}^{*}$ & ${ }^{1} \mathrm{H}-J(\mathrm{~Hz})$ & $\operatorname{HMBC}(\mathrm{C})$ & $\operatorname{COSY}(\mathrm{H})$ & $\operatorname{NOESY}(\mathrm{H})^{* *}$ \\
\hline 1 & 55.5 & $2.30,1 \mathrm{H}, m$ & & $2 \mathrm{a} / \mathrm{b}, 5$ & $1^{\prime}, 2 b, 3 a, 4,5,14$ \\
\hline \multirow[t]{2}{*}{2} & 26.9 & $1.54, m, \mathrm{H}-2 \mathrm{a}$ & & $1,2 b, 3 a / b$ & \\
\hline & & $1.72, m, \mathrm{H}-2 \mathrm{~b}$ & & $1,2 \mathrm{a}, 3 \mathrm{a}$ & $9 b, 14$ \\
\hline \multirow[t]{2}{*}{3} & 31.5 & $1.25, m, \mathrm{H}-3 \mathrm{a}$ & & $2 \mathrm{a} / \mathrm{b}, 3 \mathrm{~b}, 4$ & \\
\hline & & $1.72, m, \mathrm{H}-3 \mathrm{~b}$ & & $2 \mathrm{a} / \mathrm{b}, 3 \mathrm{a}, 4$ & \\
\hline 4 & 40.0 & $2.03, m$ & & $3 \mathrm{a} / \mathrm{b}, 15$ & $1,5,15$ \\
\hline 5 & 47.2 & $2.12,1 \mathrm{H}, m$ & & $1,6 \mathrm{a}$ & $1,6 a / b, 7,15$ \\
\hline \multirow[t]{2}{*}{6} & 28.4 & $1.23, m, \mathrm{H}-6 \mathrm{a}$ & & $5,6 \mathrm{~b}, 7$ & $8 \mathrm{a}$ \\
\hline & & $1.37, m, \mathrm{H}-6 \mathrm{~b}$ & & $6 a$ & $5,7,15$ \\
\hline 7 & 46.3 & $2.49,1 \mathrm{H}, m$ & & $6 \mathrm{a}, 8 \mathrm{a} / \mathrm{b}$ & $2^{\prime}, 5,6 \mathrm{a} / \mathrm{b}, 12 \mathrm{~b}, 13$ \\
\hline \multirow[t]{2}{*}{8} & 29.7 & $1.43, m, \mathrm{H}-8 \mathrm{a}$ & & $7,8 \mathrm{~b}, 9 \mathrm{a} / \mathrm{b}$ & $6 a$ \\
\hline & & $1.72, m, \mathrm{H}-8 \mathrm{~b}$ & & $7,8 \mathrm{a}, 9 \mathrm{~b}$ & \\
\hline \multirow[t]{2}{*}{9} & 31.4 & $1.72, m, \mathrm{H}-9 \mathrm{a}$ & & $8 \mathrm{a}, 9 \mathrm{~b}$ & \\
\hline & & $1.98, m, \mathrm{H}-9 \mathrm{~b}$ & & $8 \mathrm{a} / \mathrm{b}, 9 \mathrm{a}$ & 2a, 14 \\
\hline 10 & 83.3 & & & & \\
\hline 11 & 153.7 & & & & \\
\hline \multirow[t]{2}{*}{12} & 108.5 & $4.55,1 \mathrm{H}, m, \mathrm{H}-12 \mathrm{a}$ & 7,13 & $12 b, 13$ & \\
\hline & & $4.67,1 \mathrm{H}, m, \mathrm{H}-12 \mathrm{~b}$ & 7,13 & $12 \mathrm{a}, 13$ & 7 \\
\hline 13 & 19.8 & $1.68,3 \mathrm{H}, b s$ & $7,11,12$ & $12 \mathrm{a} / \mathrm{b}$ & 7 \\
\hline 14 & 28.1 & $1.21,3 \mathrm{H}, s$ & $1,9,10$ & & $1,1^{\prime}, 2 \mathrm{a}, 5^{\prime}, 9 \mathrm{~b}$ \\
\hline 15 & 16.7 & $0.91,3 \mathrm{H} d(6.9)$ & $3,4,5$ & 4 & $4,5,6 \mathbf{a} / \mathbf{b}, 3 \mathrm{a}$ \\
\hline $1^{\prime}$ & 96.0 & $4.74,1 \mathrm{H}, d(0.7)$ & $10,2^{\prime}$ & $2^{\prime}$ & $1,14,3^{\prime}, 5^{\prime}$ \\
\hline $2^{\prime}$ & 74.0 & $3.84,1 \mathrm{H}, d d(0.7,3.2)$ & $4^{\prime}$ & $1^{\prime}, 3^{\prime}$ & 7 \\
\hline $3^{\prime}$ & 75.8 & $3.46,1 \mathrm{H}, d d(3.2,9.5)$ & $4^{\prime}$ & $2^{\prime}, 4^{\prime}$ & $1^{\prime}, 5^{\prime}$ \\
\hline $4^{\prime}$ & 68.7 & $3.57,1 \mathrm{H}, t(9.5)$ & $3^{\prime}$ & $3^{\prime}, 5^{\prime}$ & $6{ }^{\prime} \mathrm{b}$ \\
\hline $5^{\prime}$ & 77.8 & $3.19,1 \mathrm{H}, d d d(2.5,5.5,9.5)$ & & $4^{\prime}, 6^{\prime} \mathrm{a} / \mathrm{b}$ & $14,1^{\prime}, 3^{\prime}$ \\
\hline \multirow[t]{2}{*}{$6^{\prime}$} & 63.0 & $3.68,1 \mathrm{H}, d d(5.5,11.7), \mathrm{H}-6^{\prime} \mathrm{a}$ & & $5^{\prime}, 6^{\prime} \mathrm{b}$ & \\
\hline & & $3.81,1 \mathrm{H}, d d(2.5,11.7), \mathrm{H}-6^{\prime} \mathrm{b}$ & & $5^{\prime}, 6^{\prime} \mathrm{a}$ & $4^{\prime}$ \\
\hline
\end{tabular}

${ }^{* 13} \mathrm{C}$ signals attributed on base in HSQC e HMBC correlations. **Bold face number correlations were confirmed by nOe experiments.

correlations (Table 1$)$ revealed 1 as the $(1 R, 4 S, 5 S, 7 R, 10 R)$ 10-hydroxyguaianol 10-O- $\beta$-mannopyranoside. While the opposite configuration is possible, the suggested one was made considering the literature, where guaiane-type sesquiterpenoids have mostly the $\mathrm{C}-7 R$ configuration. This was reinforced by papers shown experimental data of biosynthesis of guaianolides from (+)-germacrene A, that is a $\mathrm{C}-7 R$ result of the farnesyl diphosphate cyclization. ${ }^{7,8}$ Compound $\mathbf{1}$ is the first sesquiterpene with sugar moiety isolated from fungi. Furthermore, its novelty is in both the attachment position and type of the sugar moiety, since any sesquiterpenoid with mannose has not been described yet. All reported guaiane-type sesquiterpenoids with sugar moiety were obtained from plants, almost all of them bearing a glucose unit and presenting in many cases a $\gamma$-lactone involving the 6, 7,11 and 12 carbons.

The IR spectrum of $\mathbf{2}$ displays typical absorptions for hydroxyl and $\gamma$-lactone carboxyl groups at 3352 and 1770 $\mathrm{cm}^{-1}$, respectively. Its full scan ESI mass spectrum revealed ion peaks at $\mathrm{m} / \mathrm{z} 193\left([\mathrm{M}+\mathrm{H}]^{+}\right), 215\left([\mathrm{M}+\mathrm{Na}]^{+}\right)$and $231\left([\mathrm{M}+\mathrm{K}]^{+}\right)$. These data associated to the NMR data of 2 are coherent with the molecular formula $\mathrm{C}_{11} \mathrm{H}_{12} \mathrm{O}_{3}$ and a structure with an aromatic and a lactone ring. From NMR data analysis, 2 was identified as 3-hydroxy-5phenylmethyltetrahydrofuran-2-one. A emphasis can be give to HMBC correlations of the methylene hydrogen atoms $\mathrm{H}-4(\delta 1.90$ and 2.53$)$ with the lactone carbonyl carbon C-2 ( $\delta 176.9)$ and the carbinol carbon atoms C-3 and 
C-5 ( $\delta 68.4$ and 77.1, respectively); of the benzyl methylene hydrogen atoms ( $\delta 2.90$ and 3.09) with the C-4 $(\delta 36.5)$, $\mathrm{C}-5$ and aromatic carbons $\mathrm{C}-1^{\prime}$ and $\mathrm{C}-2^{\prime} / 6^{\prime}(\delta 135.5$ and 129.3, respectively). The other HMBC correlations as well the COSY ones are all in accord with the structure proposed above for $\mathbf{2}$. A known metabolite having a such structure is the harzialactone A, a natural product from the Trichoderma harzianum OUPS-N115, a strain isolated from the sponge Halichondria okadai. ${ }^{9}$ The stereoisomers of harzialactone A were obtained only by synthesis. ${ }^{10}$ By comparison with the NMR data of all those isomers, including harzialactone $\mathrm{A}$, the $(3 R, 5 R)$ isomer, ${ }^{10} 2 \mathrm{NMR}$ spectra were in agreement with either the $(3 R, 5 S)$ or $(3 S, 5 R)$ enantiomer data, of which the ${ }^{1} \mathrm{H}$ and ${ }^{13} \mathrm{C}$ NMR shifts for the atoms at the 3,4 and 5 positions are perceptively unlike from the respective ones in the other stereoisomers. The specific rotation of $\mathbf{2}$ indicated it as the 3-hydroxy-5phenylmethyl- $(3 S, 5 R)$-tetrahydrofuran-2-one, ${ }^{10}$ which is novel as natural product.

\section{Experimental}

\section{General}

Optical rotations were measured in $\mathrm{MeOH}$ or $\mathrm{CHCl}_{3}$, on a PERKIN-ELMER 241 polarimeter, using a $1 \mathrm{dm}$ path length cell. IR spectra were obtained in a BOMEM MB-102 spectrophotometer, in KBr pellets. NMR spectra, including ${ }^{1} \mathrm{H}-{ }^{1} \mathrm{H}-\mathrm{COSY}$, HSQC, HMBC, NOESY and nOe experiments, were recorded on a Bruker DRX spectrometer, operating at $400 \mathrm{MHz}$ for ${ }^{1} \mathrm{H}$ and $100 \mathrm{MHz}$ for ${ }^{13} \mathrm{C}$, using d-chloroform or d-methanol as solvent and TMS as the internal standard. ESI-MS data were measured in a lowresolution MICROMASS QUATRO-LC instrument.

\section{Fungus collection and identification}

Using a known procedure, ${ }^{11}$ the fungus FED-3 was isolated from the wood of the stem of Murraya paniculata collected in Águas da Prata, São Paulo State, Brazil. The fungus appeared after 30-45 days from pieces of the stem on Petri dish containing PDAY - a potato-dextroseagar medium with $0.2 \%$ yeast extract. Hyphal tips were transferred to other PDAY Petri dish. During the first week growing FED-3 typically release a stink. Its asci and conidia as well as the ITS-1 and ITS-2 rDNA sequences, with $83 \%$ sequence identity to Eutypa lata, suggested FED-3 belonging to Eutypa genus. More investigation, however, is necessary for determine the correct genus and, as well as possible the species of FED-3. The fungus has been studied both for taxonomical classification and metabolites identification. It is deposited (number LaBioMMi-204) at the Laboratório de Bioquímica Micromolecular de Microorganismos - LaBioMMi - of the Departamento de Química at Universidade Federal de São Carlos, São Carlos, Brazil.

\section{Cultivation of the fungus and metabolites isolation}

After about 30 days growing, 3-5 pieces of $8 \mathrm{~mm}$ in diameter of the PDAY culture containing FED-3's mycelium were inoculated in 48 Erlenmeyer flasks $(250 \mathrm{~mL})$ each containing $125 \mathrm{~mL}$ of PDY (potato-dextrose with $0.2 \%$ yeast extract) and incubated at room temperature $\left(25 \pm 3{ }^{\circ} \mathrm{C}\right)$ on an opened shaker (130 rpm) during 21 days. The mycelium was separated and the cultured medium, after addition of $2 \%$ isopropanol, was partitioned with ethyl acetate. The dried organic extract (180 mg) was fractionated by CC over silica gel with gradient elution with hexane, hexane-ethyl acetate (9.5:5, 9:1, 8:2, 7:3, 4:6 and 0:10), ethyl acetate-methanol (9:1, 6:4 and 0:10) and methanol-water $(9: 1 \mathrm{v} / \mathrm{v})$. The metabolites 1 ( $2 \mathrm{mg}$; from hexane-ethyl acetate 4:6 eluent) and 2 (4 mg; from ethyl acetate-methanol 6:4 eluent) were then purified by preparative TLC over Silica gel, eluted with hexane-ethyl acetate-acetone-methanol 10:0:10:0.1 and $65: 15: 15: 5$, respectively.

(1R,4S, 5S, 7R, 10R)-10-Hydroxyguaianol 10-O- $\beta$ mannopyranoside $(\mathbf{1})$

Viscid dark yellow oil; $[\alpha]^{25}-22.3(c 0.0017, \mathrm{MeOH})$; IR (KBr) $v_{\max } / \mathrm{cm}^{-1}: 3400,2934,2870,1643,1455,1380$, 1065, 1019, 909; ESIMS, daughter ions of $\mathrm{m} / z$ 383, $12 \mathrm{eV}$ : $(\mathrm{R}=$ aglycone $) \mathrm{m} / \mathrm{z}(\%) 383\left([\mathrm{M}-\mathrm{H}]^{-}, 72\right), 179([\mathrm{M}-\mathrm{H}$ $\left.-\mathrm{R}]^{-}, 37\right), 161$ ([M - H - R - $\left.\left.\mathrm{H}_{2} \mathrm{O}\right]^{-}, 16\right), 149$ ([M - H $\left.\left.\mathrm{R}-\mathrm{CH}_{2} \mathrm{O}\right]^{-}, 7\right), 143\left(\left[\mathrm{M}-\mathrm{H}-\mathrm{R}-2 \mathrm{H}_{2} \mathrm{O}\right]^{-}, 9\right), 131$ ([M $\left.\left.-\mathrm{H}-\mathrm{R}-\mathrm{CH}_{2} \mathrm{O}-\mathrm{H}_{2} \mathrm{O}\right]^{-}, 7\right), 119\left(\left[\mathrm{M}-\mathrm{H}-\mathrm{R}-2 \mathrm{CH}_{2} \mathrm{O}\right]^{-}\right.$, 100), $113\left(\left[\mathrm{M}-\mathrm{H}-\mathrm{CH}_{2} \mathrm{O}-2 \mathrm{H}_{2} \mathrm{O}\right]^{-}, 11\right), 107$ ([M - H $\left.\left.\mathrm{R}-4 \mathrm{H}_{2} \mathrm{O}\right]^{-}, 8\right), 101\left(\left[\mathrm{M}-\mathrm{H}-\mathrm{R}-2 \mathrm{CH}_{2} \mathrm{O}-\mathrm{H}_{2} \mathrm{O}\right]^{-}, 22\right)$, $89\left(\left[\mathrm{M}-\mathrm{H}-\mathrm{R}-3 \mathrm{CH}_{2} \mathrm{O}\right]^{-}, 58\right), 71\left(\left[\mathrm{M}-\mathrm{H}-\mathrm{R}-3 \mathrm{CH}_{2} \mathrm{O}\right.\right.$ $\left.-\mathrm{H}_{2} \mathrm{O}^{-}, 10\right)$; NMR spectra see Table 1.

\section{3-Hydroxy-5-phenylmethyl-(3S,5R)-tetrahydrofuran-2- one (2)}

Crystalline solid; $[\alpha]_{\mathrm{D}}^{25}-8.0\left(c\right.$ 0.0032, $\left.\mathrm{CHCl}_{3}\right)$ \{literature: $\left.[\alpha]^{25}{ }_{\mathrm{D}}-8.5\left(c 0.0011, \mathrm{CHCl}_{3}\right)\right\} ;{ }^{10} \mathrm{IR}(\mathrm{KBr}) v_{\max }$ ' $\mathrm{cm}^{-1}: 3352,1770,1451,1197,1129,990$; ESIMS, daughter ions of $m / z, 193,10 \mathrm{eV}: \mathrm{m} / z(\%) 193\left([\mathrm{M}+\mathrm{H}]^{+}, 4\right), 157([\mathrm{M}$ $\left.\left.+\mathrm{H}-2 \mathrm{H}_{2} \mathrm{O}\right]^{+}, 8\right), 147\left(\left[\mathrm{M}+\mathrm{H}-\mathrm{HCO}_{2} \mathrm{H}\right]^{+}, 100\right), 145([\mathrm{M}$ $\left.\left.+\mathrm{H}-\mathrm{H}_{2} \mathrm{O}-\mathrm{CH}_{2} \mathrm{O}\right]^{+}, 9\right), 129\left(\left[\mathrm{M}+\mathrm{H}-\mathrm{HCO}_{2} \mathrm{H}-\mathrm{H}_{2} \mathrm{O}\right]^{+}\right.$, 12), $115\left(\left[\mathrm{M}+\mathrm{H}-\mathrm{CH}_{3} \mathrm{CO}_{2} \mathrm{H}-\mathrm{H}_{2} \mathrm{O}\right]^{+}, 17\right), 91([\mathrm{M}+\mathrm{H}$ $-\gamma$-lactone ring $\left.]^{+}, 22\right)$; NMR spectra of $\mathbf{2}$ were in complete agreement with the reported data. ${ }^{10}$ 


\section{Acknowledgments}

The authors are gratefull to Fundação de Amparo à Pesquisa do Estado de São Paulo (FAPESP) and to Conselho Nacional de Desenvolvimento Científico e Tecnológico (CNPq) for financial supports. A.D.L.S thanks Coordenação de Aperfeiçoamento de Ensino Superior (CAPES) for student fellowship.

\section{Supplementary Information}

${ }^{1} \mathrm{H}$ NMR, ${ }^{13} \mathrm{C}$ NMR, HSQC and HMBC spectra of $\mathbf{1}$ are available free of charge at http://jbcs.sbq.org.br, as PDF file.

\section{References}

1. Ferracin, R. J.; PhD Thesis, Universidade Federal de São Carlos, Brazil, 1996.

2. Souza, A. Q. L.; PhD Thesis, Universidade Federal de São Carlos, Brazil, 2006.

3. Rodrigues-Filho, E.; Barros, F. A. P.; Biochem. Syst. Ecol. 2005, 33, 257.
4. Molyneux, R. J.; Mahoney, N.; Bayman, P.; Wong, R. Y.; Meyer, K.; Irelan, N.; J. Agric. Food Chem. 2002, 50, 1393.

5. Mahoney, N.; Lardner, R.; Molyneux, R. J.; Scott, E. S.; Smith, L. R.; Schoch, T. K.; Phytochemistry 2003, 64, 475.

6. Kim, J. H.; Mahoney, N.; Chan, K. L.; Molyneux, R. J.; Campbell, B. C.; Curr. Microbiol. 2004, 49, 282.

7. de Kraker, J.-W.; Franssen, M. C. R.; Joerink, M.; de Groot, A.; Bouwmeester, H. J.; Plant Physiol. 2002, 129, 257.

8. de Kraker, J.-W.; Franssen, M. C. R.; de Groot, A.; König, W. A.; Bouwmeester, H. J.; Plant Physiol. 1998, 117, 1381.

9. Amagata, T.; Usami, Y.; Minoura, K.; Ito, T.; Numata, A.; $J$. Antibiot. 1998, 51, 33.

10. Mereyala, H. B.; Joe, M.; Gadikota, R. R.; Tetrahedron: Asymmetry 2000, 11, 4071.

11. Souza, A. Q. L.; Souza, A. D. L.; Astolfi-Filho, S.; Pinheiro, M. L. B.; Sarquis, M. I. M.; Pereira, J. O.; Acta Amazônica 2004, $34,185$.

Received: October 25, 2007 Web Release Date: August 11, 2008

FAPESP helped in meeting the publication costs of this article. 


\section{A New Guaiane Mannoside from a Eutypa-like Fungus Isolated from Murraya paniculata in Brazil}

\section{Afonso D. L. Souza, ${ }^{*, \#, a}$ Edson Rodrigues-Filho, ${ }^{a}$ Antonia Q. L. Souza, ${ }^{b}$ Flavio Henrique-Silva ${ }^{b}$ and José O. Pereirac}

${ }^{a}$ Departamento de Química, Universidade Federal de São Carlos, CP 676, 13565-905 São Carlos-SP, Brazil

${ }^{b}$ Departamento de Genética e Evolução, Universidade Federal de São Carlos, CP 676, 13565-905 São Carlos-SP, Brazil

${ }^{c}$ Faculdade de Ciências Agrárias, Universidade Federal do Amazonas, 69077-000 Manaus-AM, Brazil
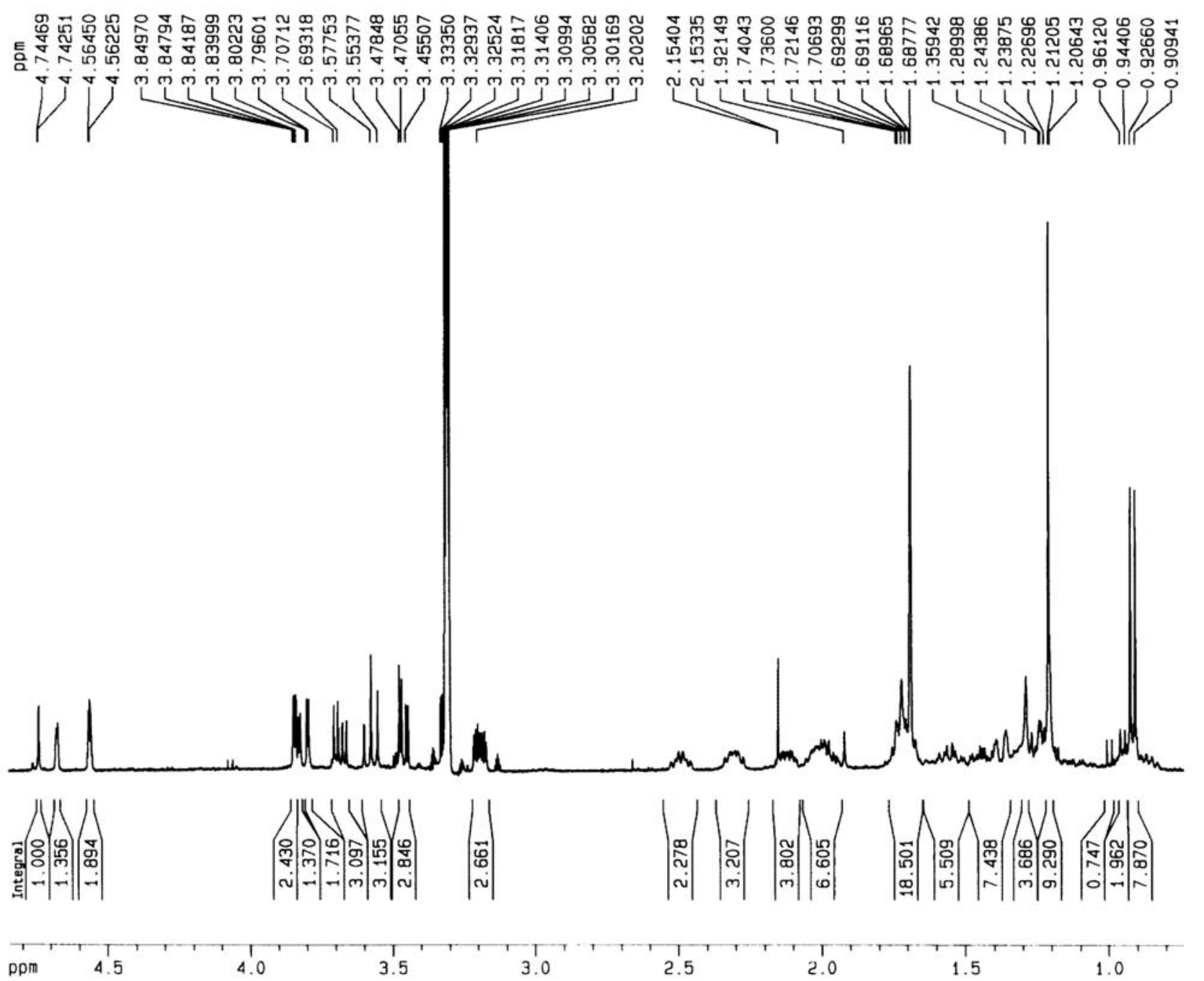

Figure S1. 'H NMR spectrum of (1) (methanol-d4, TMS).

*e-mail: souzadq@ufam.edu.br

"Present Address: Departamento de Química, Mini-Campus, Bloco B,

Sala B-13, Universidade Federal do Amazonas, 69077-000 Manaus-

AM, Brazil 


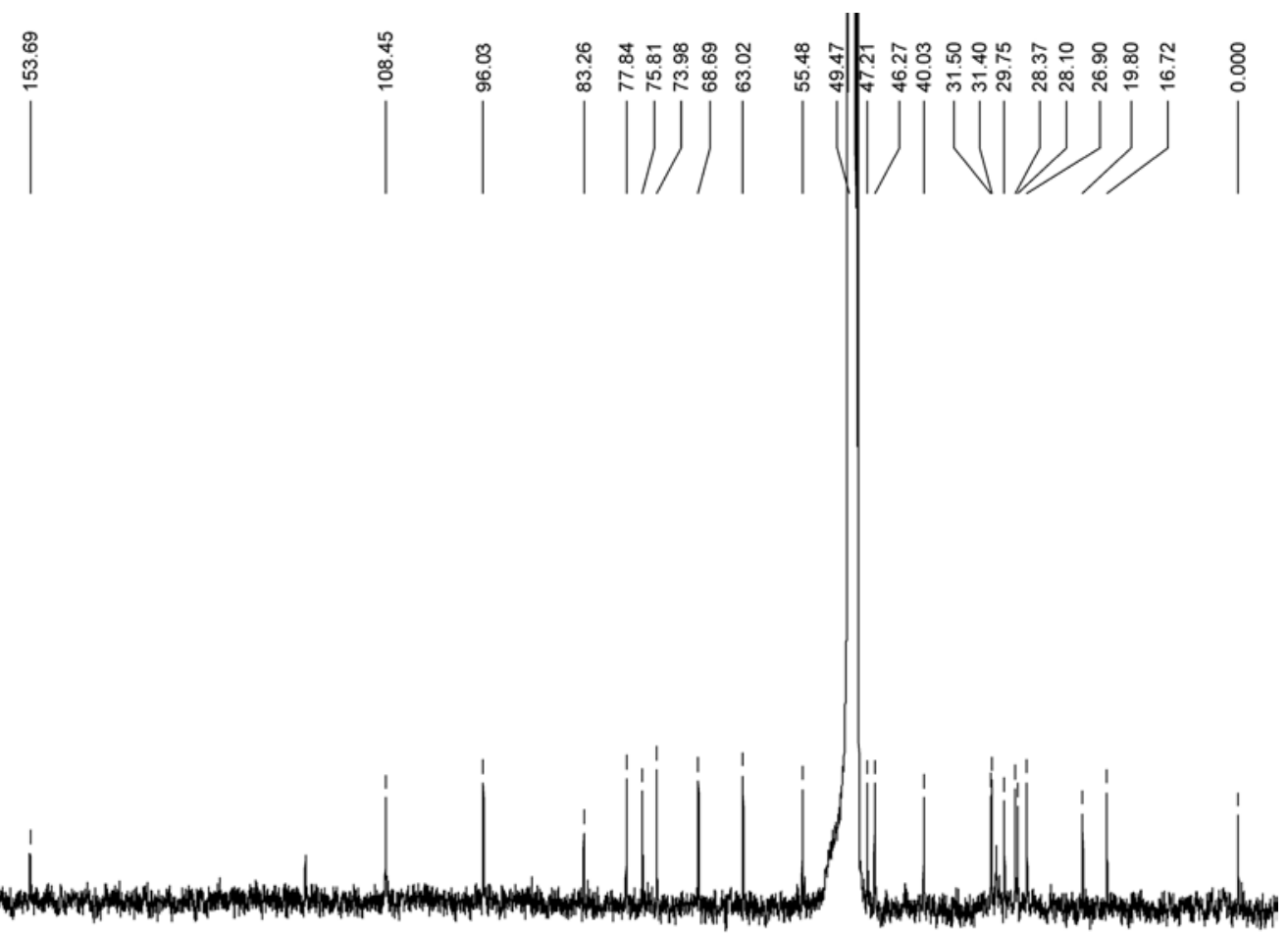

Figure S2. ${ }^{13}$ C NMR spectrum of (1) (methanol-d4, TMS).

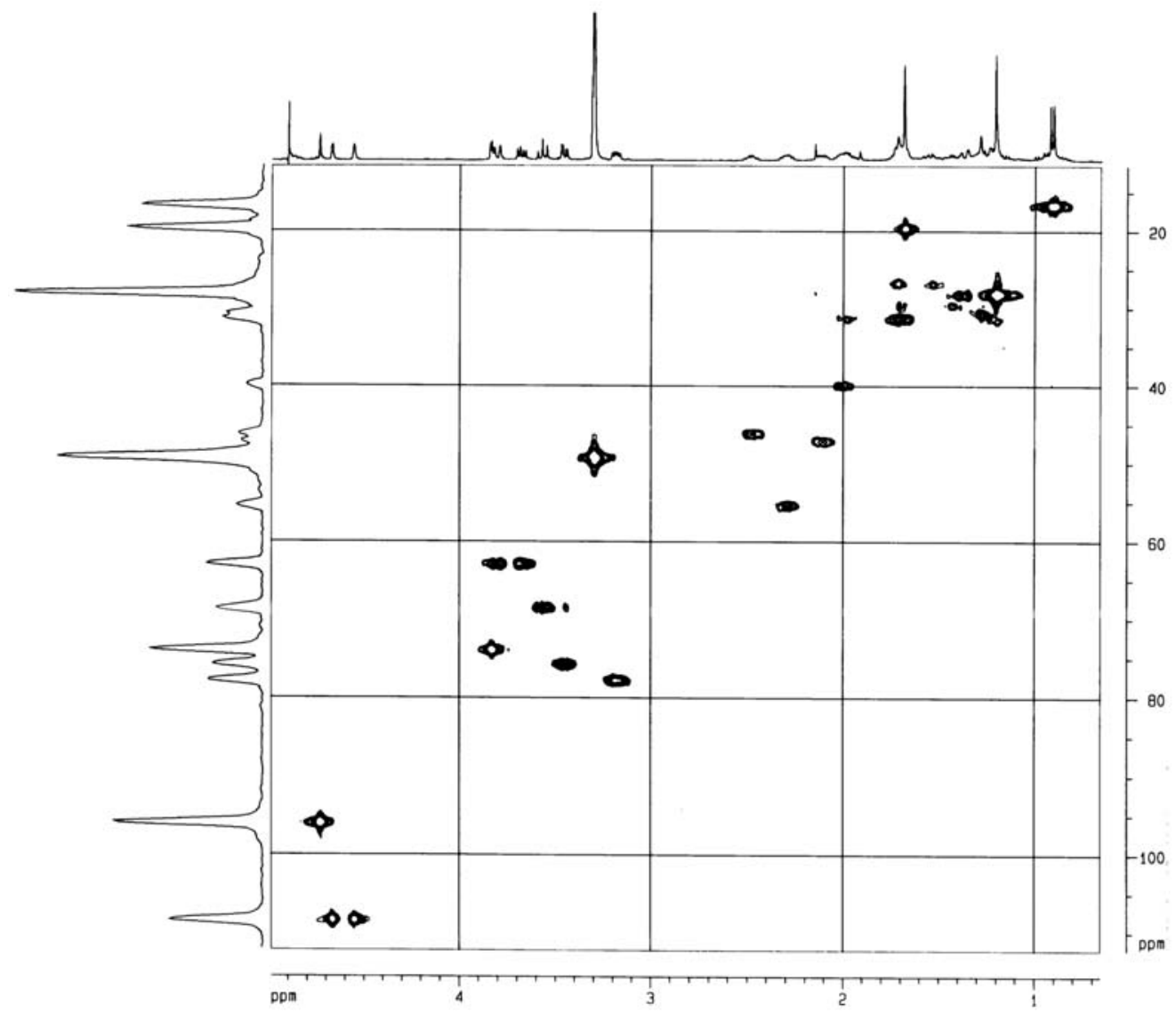

Figure S3. $g$ HSQC of (1) (methanol-d4, TMS). 


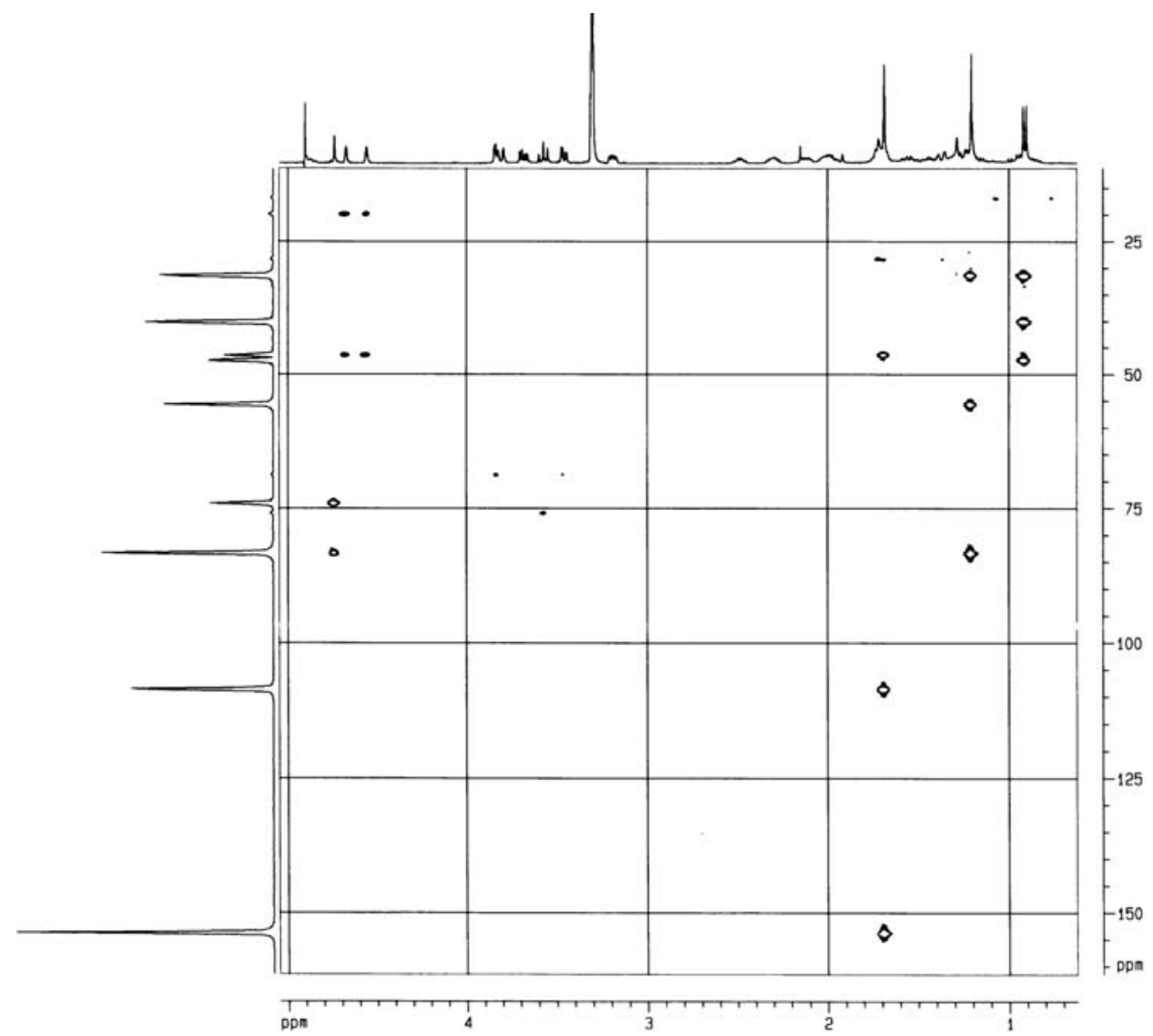

Figure S4. $g$ HMBC of (1) (methanol-d4, TMS). 